\title{
Opposite responses by an intertidal predator to increasing aquatic and aerial temperatures
}

\author{
Lauren Yamane ${ }^{1, *}$, Sarah E. Gilman ${ }^{2,3}$ \\ ${ }^{1}$ Marine Science Program, University of South Carolina, Columbia, South Carolina 29208, USA \\ ${ }^{2}$ Friday Harbor Laboratories, University of Washington, 620 University Road, Friday Harbor, Washington 98250, USA \\ ${ }^{3}$ Present address: Joint Science Department, Claremont Colleges, 925 N. Mills Road, Claremont, California 91711, USA
}

\begin{abstract}
Predicting the effects of climate change on ecosystems requires an understanding of how temperature alters organismal physiology and behavior. Because predation can shape patterns of abundance and diversity across a community, it is critical to understand the effect of temperature on predator behavior. Climate change in intertidal systems will comprise changes in both air and water temperatures, yet most previous marine intertidal studies have focused on either air or water temperature alone. In a $20 \mathrm{~d}$ laboratory study, we examined the effect of changing emersed and submersed body temperatures on the feeding and growth rates of Nucella ostrina, a common northeastern Pacific intertidal gastropod that feeds primarily on the barnacle Balanus glandula. Our results revealed a large increase in both predation and growth rates with higher submersion temperatures $\left(13.5^{\circ} \mathrm{C}\right.$ compared with $\left.11^{\circ} \mathrm{C}\right)$. In contrast, we observed a large decrease in the feeding and growth of $N$. ostrina exposed to the highest emersed body temperature $\left(28^{\circ} \mathrm{C}\right)$ when compared with intermediate $\left(20^{\circ} \mathrm{C}\right)$ and cooler $\left(12^{\circ} \mathrm{C}\right)$ aerial temperatures. Thus, while $B$. glandula may suffer greater predation-related mortality in warmer water temperatures, it may actually experience a release from predation if air temperatures warm. Our study points to the importance of considering temperatures reached during both submersion and emersion separately, and examining behavioral responses in light of physiologically relevant temperatures and thermal regimes.
\end{abstract}

KEY WORDS: Nucella $\cdot$ Intertidal $\cdot$ Physiological ecology $\cdot$ Climate change $\cdot$ Predation

\section{INTRODUCTION}

Climate change is anticipated to greatly alter many ecosystems (Walther et al. 2002, Parmesan \& Yohe 2003, Schiel et al. 2004, Jansen et al. 2007, Wethey \& Woodin 2008). Organisms inhabiting rocky intertidal zones are often living near their thermal tolerance limits (Somero 2002), making these communities sensitive indicators of climate change (Southward et al. 2004, Helmuth et al. 2005, 2006). To forecast and manage the effects of climate change, we need to be able to predict the effects of temperature on both organism physiology and species interactions (Menge \& Olson 1990, Dunson \& Travis 1991, Menge et al. 2002). Although much is known about the direct effects of temperature changes on organismal physiology in the rocky intertidal ecosystem, comparatively little is known about how ecological interactions can modulate these direct effects (but see Sanford 1999, Dahlhoff et al. 2001, Pincebourde et al. 2008, Poloczanska et al. 2008). Predation can determine patterns in abundance and diversity in a community (Connell 1961, Paine 1966, 1971, Dayton 1971, Menge 1976), and abiotic stress is well known to alter predator performance and predation rates (Menge \& Sutherland 1987, Menge \& Olson 1990). Therefore, predicting the effects of climate change on rocky intertidal communities requires understanding how temperature drives predator behavior.

To date, our understanding of how temperature mediates predator $\times$ prey interactions and foraging behavior is limited and empirical studies have yielded contrasting results (e.g. Sanford 1999, Leonard 2000, Burnaford 2004, Pincebourde et al. 2008). Consumer stress models (CSMs) propose that mobile predators 
are more susceptible to thermal stress than are their sessile prey (Menge \& Sutherland 1976, Menge \& Olson 1990). These models are based on the assumption that because sessile prey are more frequently exposed to extreme abiotic conditions, they have evolved greater tolerance of environmental extremes. Predation on these species should decline during periods of abiotic stress if their mobile predators either reduce feeding to avoid exposure or lack the resources to feed because of the costs of thermal stress. While there is some evidence that mobile intertidal predators are more sensitive to thermal stress than their prey (e.g. Petes et al. 2008), experimental tests of the CSM have been inconclusive (Menge et al. 2002). Moreover, under some conditions the reverse may be likely, especially when the predators are better able than their prey to thermoregulate (Broitman et al. 2008).

Understanding the effect of environmental stress on predator $\times$ prey interactions requires that we determine both the effects of climate on the body temperatures of predator and prey and the effect of body temperature on prey foraging behavior (Pincebourde et al. 2008). While many intertidal studies have examined the effects of temperature on predation rates, most attempt to correlate singular environmental parameters such as air or water temperatures with organism response (Bayne \& Scullard 1978, Burrows \& Hughes 1989, Sanford 2002a). These correlations may exist under some scenarios, but habitat temperature is often only loosely coupled with body temperature (Helmuth 1998, Gilman et al. 2006). Thus, it is important to link body temperature, and not just environmental temperature, to physiological responses and predation rates directly. Moreover studies that do experimentally manipulate body temperatures (Stickle et al. 1985, Sanford 2002b) often fail to test both relevant air and water temperatures or use thermal regimes that incorporate a realistic tidal cycle (Yee \& Murray 2004). Unless body temperatures are manipulated in both air and water under controlled laboratory conditions, we inhibit both our understanding of the physiological mechanism driving predator response to temperature and our ability to predict the effect of changing thermal regimes on intertidal systems.

Snails in the genus Nucella (dogwhelks) are small muricid gastropods that inhabit rocky intertidal zones worldwide. Dogwhelks consume mainly sessile invertebrates, including a variety of barnacle species that provide the physical structure and trophic foundation for rocky intertidal ecosystems (Glynn 1965). Dogwhelks regulate both barnacle abundance and distribution (Connell 1961, 1970), making dogwhelk-barnacle systems ideal for investigating the consequences of temperature for species interactions.

Field studies suggest that stress reduces the effec- tiveness of Nucella as a predator, as dogwhelks will often not forage during hot low tides (Burrows \& Hughes 1989), and feeding rates are depressed unless shelter is provided (Dahlhoff et al. 2001). Thus, increased air temperatures are thought to negatively affect Nucella performance as predicted by CSMs. However, the extent to which predation rates vary as a function of aerial temperatures remains unresolved since feeding rates have not been measured in conjunction with Nucella aerial body temperatures. Moreover, as intertidal organisms experience both terrestrial and marine conditions on a daily basis measuring Nucella predation in relation to stressful emersed (aerial) and submersed (aquatic) body temperatures remains crucial to understanding predatory responses to climate change. Although a number of laboratory studies have examined dogwhelk feeding rates under increasing water temperatures, these investigations have found conflicting results, with some measuring increased feeding (e.g. Bayne \& Scullard 1978, Sanford 2002a) and others measuring decreased feeding rates (e.g. Stickle et al. 1985). Moreover, no study has considered the effects of aerial exposure concurrently with changes in submersion temperature.

Here we report the results of a controlled laboratory study examining the effects of changes in air and water temperature on the feeding and growth of Nucella ostrina from San Juan Island, Washington, USA. Temperature regimes were chosen to match the range of body temperatures normally experienced by $N$. ostrina during summer on San Juan Island. To develop a physiologically based, mechanistic understanding of the role of temperature in driving the predation responses of $N$. ostrina, we examined the growth rates of dogwhelks at various emersed and submersed body temperatures. Over a 20 d period, we manipulated aquatic and aerial body temperatures over a simulated tidal cycle to ask (1) Will warmer submersed body temperatures increase or decrease $N$. ostrina predation and growth rates? (2) Will snails respond to warmer emersed temperatures in a similar or different manner than to warmer submersed temperatures?

\section{MATERIALS AND METHODS}

Collection and storage of animals. Laboratory experiments were conducted at the Friday Harbor Laboratories (FHL) on San Juan Island during August 2007. Nucella ostrina were collected from Colin's Cove (Dayton 1971), a wave-protected rocky intertidal site on the FHL property $\left(48.5494^{\circ} \mathrm{N}, 123.0059^{\circ} \mathrm{W}\right.$; see Fig. 1 in Yamane 2008). Barnacles Balanus glandula were collected on cobbles obtained from Argyle Creek (Nelson 1997), a saltwater creek that connects Griffin 
Bay and Argyle Lagoon, approximately $4 \mathrm{~km}$ south of FHL (Fig. 1 in Yamane 2008).

We selected relatively narrow size ranges of Nucella ostrina and Balanus glandula to limit the potential effects of predator or prey size on the measured responses. The size ranges used (3 to $5.5 \mathrm{~mm}$ opercular length for B. glandula and 14 to $18.5 \mathrm{~mm}$ shell height for N. ostrina) approximate the optimal sizes of each species for maximal N. ostrina growth rates (Palmer 1983).

Both Balanus glandula and Nucella ostrina were continuously submerged in a running seawater table at FHL $\left(\sim 13^{\circ} \mathrm{C}\right)$ for at least $2 \mathrm{wk}$ before inclusion in the experiment to ensure that all animals had the same initial thermal history. During this storage phase, $N$. ostrina were provided with barnacles ad libitum from the same population as those used throughout the experiment.

Temperature treatments. All experiments were conducted in a controlled temperature room at FHL. To assess the effect of emersion and submersion temperatures on Nucella ostrina we subjected snails to 1 of 4 temperature treatments. In 3 of the treatments, submersion temperatures were held fixed $\left(11.0 \pm 0.2^{\circ} \mathrm{C}\right)$ and snails experienced 1 of 3 emersion temperatures: the control temperature of $11.8 \pm 0.3^{\circ} \mathrm{C}$ (set by the temperature of the room), $20.4 \pm 0.6^{\circ} \mathrm{C}(20 \mathrm{E} / 11 \mathrm{~S}$, where $20 \mathrm{E}$ is the emersion temperature and $11 \mathrm{~S}$ is the submersion temperature $\left.\left[{ }^{\circ} \mathrm{C}\right]\right)$, or $27.6 \pm 1.7^{\circ} \mathrm{C}(28 \mathrm{E} / 11 \mathrm{~S})$. In the 4 th treatment, the emersion temperature was held fixed at $11.4 \pm 0.6^{\circ} \mathrm{C}$ and snails experienced a warmer submersion temperature of $13.5 \pm 0.3^{\circ} \mathrm{C}(12 \mathrm{E} / 13.5 \mathrm{~S})$. Submersion and emersion temperatures were monitored using physical models (silicone-filled $N$. ostrina shells) placed into treatment tanks. Thermocouple temperature sensors were inserted into the physical models and connected to a Campbell CR10X datalogger (Campbell Scientific) that recorded model body temperatures at 1 min intervals. Tanks were monitored on a rotating basis throughout the experiment.

The 3 low tide temperature treatments (control, 20E/11S and 28E/11S) reflect the range of daytime low tide body temperatures experienced by Nucella ostrina during the summer months at Friday Harbor (S. E. Gilman \& E. Carrington unpubl. data). Because snails in the field do not usually experience more than one daytime low tide per day, the second low tide exposure of the day was not heated for any treatment. The heated emersion treatments (20E/11S and 28E/11S) were generated by porcelain infrared heat bulbs (40 and $60 \mathrm{~W}$ Exo Terra Heat Wave Lamps, Rolf C. Hagen) held at different heights above the tanks. Snail heating rates during emersion were matched to those experienced by $N$. ostrina in the field. At the onset of low tide, the snails gradually heated to the treatment temperature during the first $3 \mathrm{~h}$ and remained at this temperature over the final $3 \mathrm{~h}$. In some cases, the temperature continued to increase slightly until the snails were resubmerged. For these tanks, the treatment temperature represented the mean value during the final $3 \mathrm{~h}$ of emersion. Rates of heating in the lab for the 20E/11S treatment (about $3^{\circ} \mathrm{C} \mathrm{h}^{-1}$ ) were similar to those seen in the field $\left(2\right.$ to $5^{\circ} \mathrm{C} \mathrm{h}^{-1}, \mathrm{~S}$. E. Gilman \& E. Carrington unpubl. data). Heating curves for the 28E/11S treatment (just under $6^{\circ} \mathrm{C} \mathrm{h}^{-1}$ ) were only slightly higher than those seen in the field, but were necessary to expose snails in both heated treatments to the same number of hours at the designated treatment temperature.

The warmer submersion temperature treatment (12E/13.5S) was generated by placing a $250 \mathrm{~W}$ aquarium heater attached to a temperature controller (Biotherm Dual Monitor and Controller, Aqua Medic) into one of the storage tanks (Fig. 2 in Yamane 2008), which supplied seawater to treatment tanks during high tide and stored seawater drained from treatment tanks during low tide.

Experimental tank setup. Each temperature treatment required 6 replicate, 61 plastic experimental treatment tanks. The replicates were haphazardly placed throughout the room (Fig. 2 in Yamane 2008) to minimize the effect of tank location on snail response. The tanks experienced a semi-diurnal tidal cycle that alternated $6 \mathrm{~h}$ long high tides with equal duration low tides. This cycle of submersion and emersion approximates the tidal cycle experienced by Nucella ostrina in the summer at FHL, where this species experiences on average 5 to $7 \mathrm{~h}$ per day of daytime exposure during May to August (S. E. Gilman unpubl. data) due to its upper-mid intertidal distribution (Connell 1970). During high tide, aerated seawater was continuously circulated between the experimental tanks and storage tanks. At low tide, pumps were turned off, allowing seawater to drain back into the storage tanks, but leaving approximately $2 \mathrm{~cm}$ of water at the bottom of the experimental tanks. Two dogwhelks were placed within each experimental tank, and each snail was housed within a separate $10 \mathrm{~cm}^{3}$ plastic container that elevated snails above the low tide water level. Tanks were insulated from each other by $2.5 \mathrm{~cm}$ styrofoam walls and tops, keeping dogwhelks in dark conditions throughout the experiment. As tanks were enclosed and standing water remained at low tide, we estimated that air within the experimental tanks approached saturation, which allowed us to isolate the effect of temperature from the confounding effect of desiccation.

To allow for the circulation of seawater throughout the experimental tank, 2 of the plastic sidewalls and the lid on each plastic container were replaced with fine mesh window screen. The floor of each container was covered in modeling clay, into which we embedded small rocks containing a total of 20 barnacles. The 
clay created a thermally homogeneous environment for the whelk by filling in the concavities of the cobbles where water would otherwise accumulate during low tide. Seawater was replaced every $5 \mathrm{~d}$. Salinity never dropped below 29 (Friday Harbor typically fluctuates from 28 to 31; Mills 1984), ammonia concentrations remained at 0 and $\mathrm{pH}$ levels were consistently 8 in all treatments throughout the study.

Data collection and analysis. Three tanks were excluded from statistical analyses. In one case, the tank temperatures varied greatly from those of the other treatment tanks. In another case, the snails had escaped from their individual plastic containers. The third tank was eliminated from analysis following mortality of both snails during the second half of the experiment. Average emersion and submersion treatment temperatures and SD values were calculated from the remaining monitored tank temperatures over the final $3 \mathrm{~h}$ of the heated emersion or submersion period.

We assessed Nucella ostrina growth as change in snail mass, total length and new shell added. Snail mass was measured on snails air-dried for $6 \mathrm{~h}$, after removing as much extravisceral mantle water as possible (Palmer 1982). Shell length was measured as the total distance from the siphonal canal of the aperture to the shell apex using vernier calipers. Mass and length changes were normalized by dividing changes in mass or length by the initial values measured. To quantify shell growth, a thin line of nail polish was applied to the leading edge of the aperture at the start of the experiment (Kenny 1977). Shell growth was measured as new shell added beyond the nail polish line.

The total number and mass of barnacles consumed was assessed after 10 and $20 \mathrm{~d}$. Barnacles were considered consumed when light pressure on the opercular plates resulted in the collapse of the plates, indicating that the organism was missing from its shell. We calculated barnacle tissue mass (ash-free dry weight) from opercular length measurements using a regression equation developed by Palmer (1980) for Argyle Creek Balanus glandula. For all analyses, we summed the observations from 10 and 20 d into a single observation for each snail. To determine whether any changes in feeding occurred over time and whether these changes varied according to temperature treatment, we calculated the means and SDs of barnacle tissue mass consumed for each time period separately and also conducted a repeated measures analysis in Proc GLM of SAS v. 9.1 (SAS Institute).

The effects of submersion temperature on all 3 growth (wet weight, length and shell addition) and 2 predation (number of barnacles and barnacle tissue consumed) variables were evaluated on values averaged across within-tank replicates using single factor Model I ANOVAs in JMP 5.1.2 (SAS Institute). Welch ANOVAs that assume unequal variances were employed to evaluate the effect of emersion temperatures on feeding and growth variables due to heteroscedastic variances. To control for experiment-wise error resulting from the use of the control treatment in both submersion and emersion comparisons an alpha value of 0.025 was used for all ANOVAs. Pairs of treatment means were compared using Tukey-Kramer post hoc tests.

\section{RESULTS}

\section{Effects of body temperature on predation rates}

Nucella ostrina predation rates varied significantly among emersion treatments, both in terms of the number of barnacles $\left(F_{2,8.0}=55.34, \mathrm{p}<0.0001\right)$ and total mass consumed $\left(F_{2,8.4}=50.62, \mathrm{p}<0.0001\right)$ (Fig. $\left.1 \mathrm{~A}\right)$. Dogwhelks exposed to the highest emersed body temperature (28E/11S) consumed approximately $75 \%$ fewer Balanus glandula individuals and significantly less tissue mass than dogwhelks in either of the other 2 emersion treatment tanks $(p<0.05)$. No difference in prey consumption rates (either number or tissue mass) of $N$. ostrina was detected between the control and the 20E/11S treatment (Fig. 1A).

Nucella ostrina exposed to the higher submerged temperature treatment consumed a greater number of Balanus glandula than did the control group $\left(F_{1,8}=\right.$ $20.39, \mathrm{p}=0.0020)$. The predation rates of snails exposed to the 12E/13.5S submersion treatment were almost 1.5 times larger than those of control treatment snails (Fig. 1B). Dogwhelks in the warmer submersion temperature treatment also consumed more total prey tissue mass $\left(F_{1,8}=17.52, \mathrm{p}=0.0031\right.$; Fig. 1B). Prey consumption declined after the first $10 \mathrm{~d}$ in all 4 treatments $\left(F_{1,17}=180.25, \mathrm{p}<0.0001\right)$.

\section{Effects of body temperature on growth rates}

Patterns in Nucella ostrina growth rates closely mirrored those of predation rates. Growth in snail mass was significantly different among emersion temperature treatments $\left(F_{2,7.1}=44.07, \mathrm{p}<0.0001\right)$ (Fig. 2A). Dogwhelks that experienced the warmest temperature treatment during low tide added only about one-quarter of the normalized mass that their control and 20E/11S counterparts did over the $20 \mathrm{~d}$ experiment $(\mathrm{p}<0.05)$ (Fig. 2A). Similarly, measurements of $N$. ostrina shell and length growth revealed significant differences among emersion treatment means (length: $F_{2,6.7}=$ 21.11, $\mathrm{p}=0.0013$; shell: $F_{2,7.2}=23.70, \mathrm{p}=0.0007$ ). Again, the 28E/11S snails added significantly less new shell and normalized length than did snails exposed to 


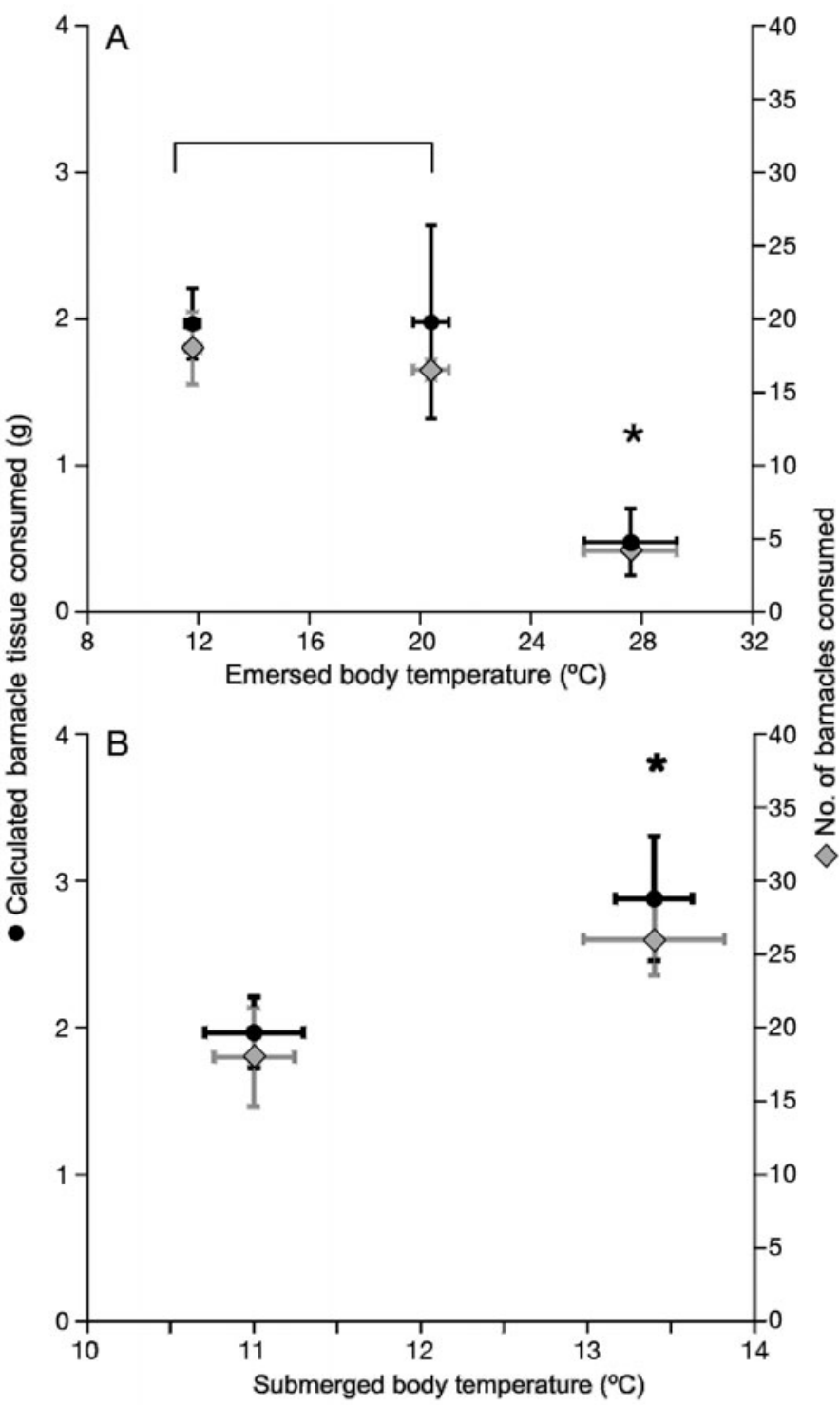

Fig. 1. Nucella ostrina. Differences in consumption of the prey Balanus glandula by the gastropod predator for (A) the 3 different emersed treatments and (B) the 2 different submersed treatments. $x^{-}$and $y$-axis error bars represent $1 \mathrm{SD}$. An asterisk $\left({ }^{*}\right)$ indicates that the response treatment mean is significantly different from those of other treatments

either of the 2 cooler emersion temperatures $(p<0.05)$, but no difference was detected between the other 2 treatments. Differences in $N$. ostrina shell growth among emersion temperature treatments were particularly pronounced, with mean shell growth of control and 20E/11S snails exceeding that of 28E/11S dogwhelks by nearly an order of magnitude (Fig. 2B).

Increasing body temperature during submersion had the opposite effect on Nucella ostrina growth. Mean growth in normalized snail mass was significantly higher in the 12E/13.5S treatment compared with the
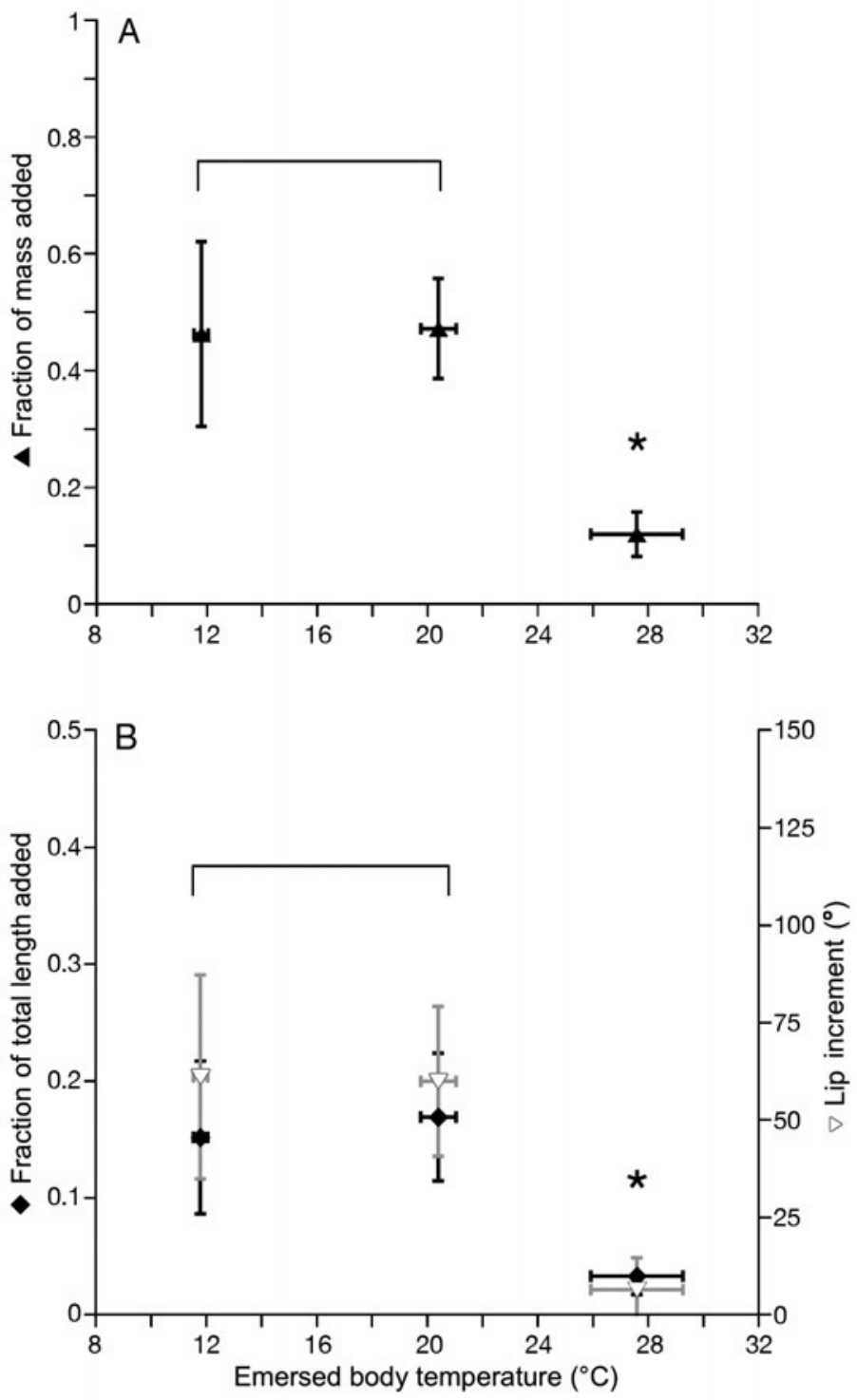

Fig. 2. Nucella ostrina. Growth in (A) mass and (B) shell of snails exposed to 3 different emersion body temperature regimes (control $\left[\sim 12^{\circ} \mathrm{C}\right], \sim 20^{\circ} \mathrm{C}$ and $\sim 28^{\circ} \mathrm{C}$ ). All error bars represent $1 \mathrm{SD}$. An asterisk $\left({ }^{*}\right)$ indicates that the response treatment mean is significantly different from those of other treatments

control treatment $\left(F_{1,8}=12.71, \mathrm{p}=0.0073\right)$ (Fig. 3A), as was mean growth in shell $\left(F_{1,8}=16.10, \mathrm{p}=0.0039\right)$ and normalized length $\left(F_{1,8}=10.58, \mathrm{p}=0.0117\right)$ (Fig. $\left.3 \mathrm{~B}\right)$. Dogwhelks experiencing warmer body temperatures during high tide added almost twice the amount of normalized snail mass that control treatment dogwhelks did (Fig. 3A). An approximate 2-fold difference in growth was also seen in the 2 other growth measurements, with the warmer submersion body temperature treatment resulting in increased $N$. ostrina shell addition and normalized length added (Fig. 3B). 


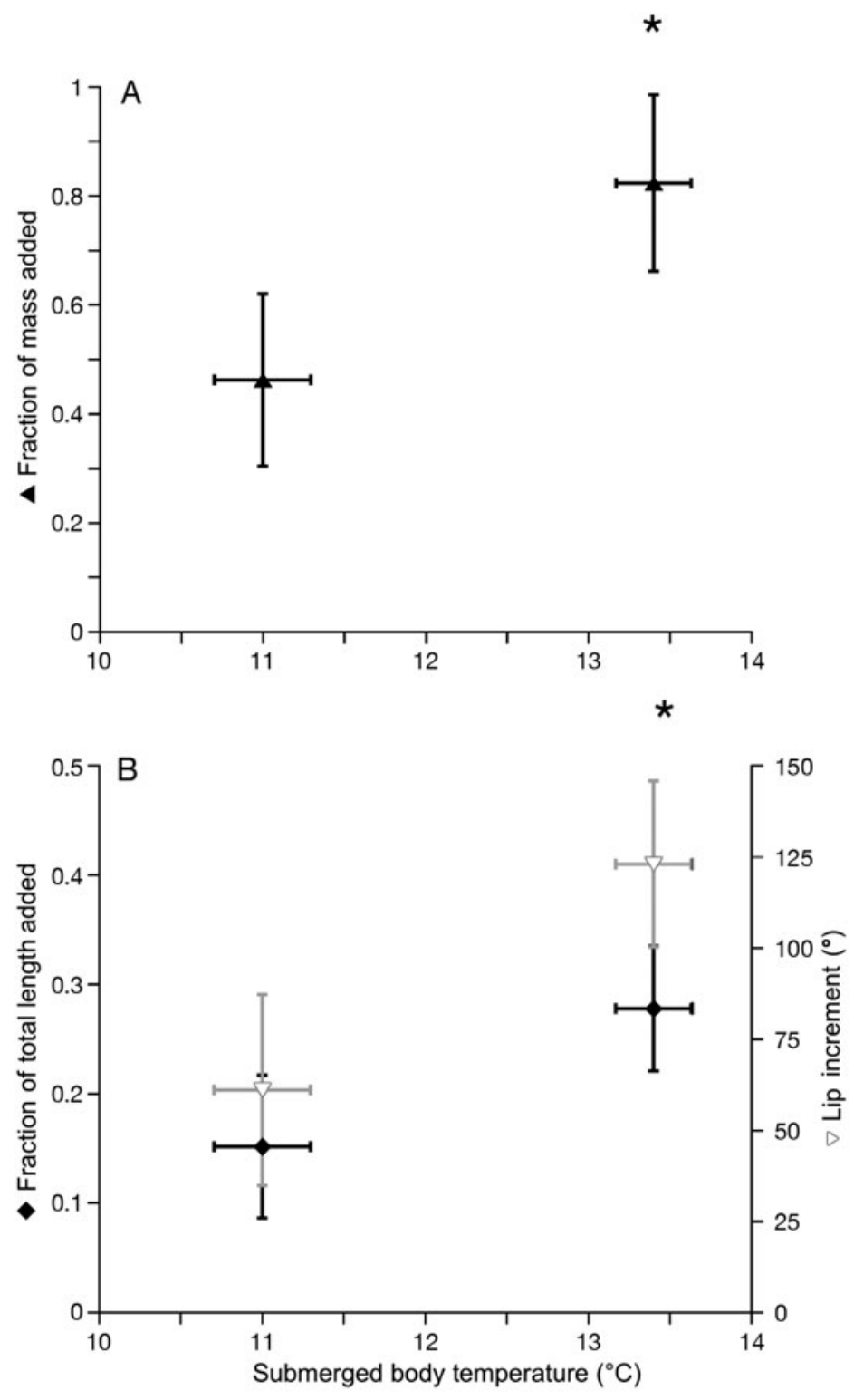

Fig. 3. Nucella ostrina. Growth in (A) mass and (B) shell of snails exposed to 2 different submersion body temperature regimes $\left(\sim 11^{\circ} \mathrm{C}\right.$ and $\left.\sim 13.5^{\circ} \mathrm{C}\right)$. All error bars represent $1 \mathrm{SD}$. An asterisk $\left({ }^{*}\right)$ indicates that the response treatment mean is significantly different from those of other treatments

\section{DISCUSSION}

Nucella ostrina exhibited dramatically different responses to increases in submersed and emersed body temperatures. Whereas feeding and growth rates significantly decreased with increasing aerial body temperature, the opposite pattern occurred with increasing submerged body temperature. These results suggest 2 distinct scenarios for $N$. ostrina's main prey, Balanus glandula, at this site. Under warming water temperatures, B. glandula may, depending on the de- gree and duration of the thermal exposure, experience greater predation pressure; yet, warming in terrestrial climates may actually reduce $N$. ostrina's predation on B. glandula. While there are limitations and caveats, which are discussed later, our results clearly demonstrate the importance both of considering the physiological effects of changes in aerial and aquatic body temperatures separately and of the subsequent community consequences likely to result from changes in aquatic and aerial thermal regimes.

\section{Effects of increasing aquatic body temperature on predation}

The $\mathrm{Q}_{10}$ effect predicts a 200 to $300 \%$ increase in metabolic activity rates for each $10^{\circ} \mathrm{C}$ temperature rise, as long as the higher temperature occurs within the organism's normal thermal range (Randall et al. 2002). Thus, raising body temperature by only a few degrees should cause significant increases in a variety of physiological rates (Prosser \& Brown 1961, Hochachka \& Somero 2002), including those involved in feeding (Bayne \& Scullard 1978, Stickle et al. 1985, Burrows \& Hughes 1991), prey handling (Yamamoto 2004) or movement (Bertness \& Schneider 1976). If warmer water temperatures decreased the time needed for digestion or prey handling, or increased movement rates, the overall time necessary to locate, attack and consume a prey item may have decreased.

Many other studies of intertidal ectotherms (e.g. Newell et al. 1971, Bayne \& Scullard 1978, Sanford 1999, 2002a,b, Yamamoto 2004) have reported higher feeding rates under increased submersion temperatures. However, these studies tested water temperatures on continuously submerged animals. Our experiment exposed snails to alternating $6 \mathrm{~h}$ submersion and emersion periods, similar to what they probably experience in the field (S. E. Gilman unpubl. data). Our results indicate that even with extended breaks from warmer submersion temperatures, dogwhelk feeding rates increase with increased water temperatures.

\section{Effects of increasing aerial body temperature on predation}

Nucella ostrina in the 28E/11S emersion treatment showed a considerable decrease in predation activity, suggesting that high body temperatures reached during low tide can significantly reduce feeding. This result was unexpected, given that snails can only initiate an attack during submersion (Emlen 1966, Bertness \& Schneider 1976). These reduced feeding rates could be caused by either a behavioral shift or by the physio- 
logical demands of warmer emersion temperatures. In the first case, Nucella spend a large proportion of their time in the cracks and crevices of the rock between foraging bouts (Hughes \& Drewett 1985, Fairweather 1988, Hughes et al. 1992) and increase their sheltering during periods of high aerial temperatures or wave action (Emlen 1966, Spight 1982, Burrows \& Hughes 1989, Jones \& Boulding 1999). A 3 h exposure to $33^{\circ} \mathrm{C}$ is the lethal limit for emersed $N$. ostrina (collected from Lummi Island, Washington; Bertness \& Schneider 1976). Aerial temperatures only a few degrees below this threshold may cause $N$. ostrina to increase time spent either being inactive or seeking shelter, instead of foraging. Similarly, field studies using shading manipulations regularly show that reduced aerial temperatures can increase prey mortality by altering the presence or abundance of ectotherm predators (e.g. Leonard 2000, Harley \& Lopez 2003). Alternately, $28^{\circ} \mathrm{C}$ may pose such great thermal stress for $N$. ostrina that the physiological cost incurred prevents the animal from engaging in the foraging or feeding process (Dahlhoff et al. 2001, Somero 2002). In this case, after repeated exposure to stressful temperatures, snails may need to devote any remaining energy to cellular maintenance and repair, rather than to crawling, drilling, and ingesting prey. Our results cannot determine whether 28E/11S snails chose sheltering over feeding or whether snails were too physiologically stressed to feed. Differentiating between these 2 hypotheses requires additional studies that simultaneously monitor dogwhelk movements and physiological indicators of stress.

\section{Effects of increasing aquatic body temperature on growth}

Nucella ostrina grew more in warmer water temperatures than in cold temperatures. Because growth represents the energetic gain of food ingested through predation minus energy used for digestion, absorption and metabolic costs (Burrows \& Hughes 1991), increases in feeding will lead to proportional increases in growth unless high physiological costs are also incurred (Jansen et al. 2007). Because growth increases were proportional to increases in feeding, there is no evidence that the warm submersion treatment was stressful to $N$. ostrina. This is not surprising given that water temperatures routinely reach or exceed $13.5^{\circ} \mathrm{C}$ in the San Juan Islands (available at: http://tidesand currents.noaa.gov/). A similar study conducted on continuously submerged $N$. canaliculata measured higher growth rates for warmer $\left(12^{\circ} \mathrm{C}\right)$ than for cooler $\left(9^{\circ} \mathrm{C}\right)$ submersed dogwhelks during the first $4 \mathrm{wk}$, but found that growth rates dropped after a longer exposure period (Sanford 2002b). Sanford (2002b) did not include aerial exposure in his experiments and it remains unclear whether we would have seen a reduction in growth rates if we had run our experiments longer.

\section{Effects of increasing aerial body temperature on growth}

The near lack of growth at the highest emersion temperature coupled to similarly low rates of predation suggests that Nucella ostrina repeatedly exposed to $28^{\circ} \mathrm{C}$ experience extreme stress. Field measurements of $N$. ostrina temperatures indicate that dogwhelks may be exposed to $28^{\circ} \mathrm{C}$ aerial temperatures only a few times a year during the summer at FHL and almost never experience the $33^{\circ} \mathrm{C}$ lethal limit observed by Bertness \& Schneider (1976) (S. E. Gilman \& E. Carrington unpubl. data). Furthermore, dogwhelks may be able to avoid $28^{\circ} \mathrm{C}$ aerial body temperatures altogether by sheltering in cooler microhabitats. Behavioral thermoregulation may allow the snails to avoid thermal stress during emersion and its resultant decreases in growth, although observations of $N$. ostrina in the field suggest that they do not always choose to do so (Dahlhoff et al. 2001).

Snail growth at 20E/11S was very similar to the control treatment. Given that energy demand generally scales with temperature (Sanford 2002b, Brown et al. 2004 ), one would expect 20E/11S snails to show an intermediate level of growth between the control and the 28E/11S treatment. There are at least 2 possible explanations for this pattern. First, many intertidal ectotherms reduce metabolic activity at low tide to minimize demands for water and oxygen (e.g. Shick et al. 1988, Fields et al. 2006). Thus, snails may not incur metabolic costs for elevated aerial temperatures until temperatures exceed the threshold for cellular damage. Because Bertness \& Schneider (1976) observed Nucella ostrina to be crawling during aerial exposure at temperatures up to $25^{\circ} \mathrm{C}$, it seems unlikely that the $N$. ostrina in our experiment would cease all metabolic activity at $20^{\circ} \mathrm{C}$. Alternately N. ostrina's metabolic rates, and subsequent growth, may be a nonlinear function of temperature. This would mean that an intermediate temperature might not produce an intermediate level of performance. Nonlinear thermal performance curves are common in both terrestrial and aquatic species (Angilletta 2009), but have not been reported specifically for $N$. ostrina during aerial exposure.

\section{Contrasting effects of air and water temperature}

The 12E/13.5S submersion treatment and 28E/11S emersion treatment temperatures both approach the 
upper thermal limits typically experienced during each tidal phase by Nucella ostrina at FHL. Yet, dogwhelk growth and feeding increased in one treatment and decreased in the other. These opposite responses suggest that these snails may be living closer to thermal maxima during low tide than during high tide. In particular, warm aerial temperatures may be avoided by sheltering at low tide, while snails have no refuge from elevated water temperatures. Thus, selection for thermal tolerance of water temperatures may be stronger than for aerial temperatures.

It was also surprising that 20E/11S snails showed no response while 12E/13.5S snails, which experienced a much lower increase in temperature, showed considerable changes in behavior and growth. The greater response to water temperature might reflect a warmer overall body temperature because of the longer total daily exposure to elevated submersion temperatures than to emersion temperatures. This could have accelerated predation, allowing for greater feeding and growth. However, when we calculated mean daily body temperatures for the $20 \mathrm{E} / 11 \mathrm{~S}$ and $12 \mathrm{E} / 13.5 \mathrm{~S}$ treatments, we found less than a $0.25^{\circ} \mathrm{C}$ difference between the 2 treatments, compared with more than $1^{\circ} \mathrm{C}$ difference between each and the control treatments. Thus, because changes in water rather than air temperatures seem responsible for metabolic changes in activity rates, either Nucella ostrina do not digest prey during low tide or it is prey handling or crawling instead, both of which occur primarily during high tide (Bertness \& Schneider 1976), that limits dogwhelk predation and growth.

These contrasting responses to aerial and aquatic temperatures suggest vastly differently effects of future warming during the 2 tidal phases: elevated submersion temperatures will alter the rate at which feeding occurs, while elevated emersion temperatures can limit feeding completely. This difference in response has clear consequences for Balanus glandula, which would experience greater predation at warmer water temperatures, but perhaps a release from predation as air temperatures warm. Whether this release occurs will depend on the degree to which Nucella ostrina can avoid stressful aerial exposures while still maintaining predation rates. It should also be noted that our study examined conditions of chronic elevated temperatures, and Pincebourde et al. (2008) have shown ectothermic intertidal predators can respond differently to intermittent and chronic aerial thermal stress. Additionally, as water temperature is both more thermally stable and less avoidable than terrestrial temperatures for mobile predators like Nucella, changes in aquatic temperatures may well determine the outcome of dogwhelk-barnacle interactions, with cascading effects for other community members. As many ectotherms are known to acclimate to water temperature, however, the degree to which acclimation might affect predation and growth over a longer study remains to be determined.

Our observation of reduced predation during warm emersed temperatures are consistent with the CSM (Menge \& Sutherland 1976, Menge \& Olson 1990), suggesting that mobile predators like Nucella ostrina may experience greater stress during low tide than do their sessile prey. In contrast, our results for submersed snails show inconsistencies with the CSM, since higher aquatic temperatures seemed to enhance predator performance and growth. However, because it is possible that aquatic temperatures were not high enough to induce stress in N. ostrina, a broader range of aquatic temperatures should be examined. Furthermore, a complete test of the CSM for aerial thermal stress requires manipulating both dogwhelks and Balanus glandula simultaneously to determine whether the reduction in predation outweighs any increases in thermal stress experienced by B. glandula.

While this study highlights clear differences in the response of Nucella ostrina to increased aquatic and aerial temperatures, our experiments focused on a single population of $N$. ostrina during one time of year, and it is possible that either other dogwhelk populations, or this population in other seasons, could show vastly different tolerances of air and water temperatures (Stillman \& Somero 2000, Stillman 2003, Sorte \& Hofmann 2005). As a direct developer, N. ostrina has a high potential for local adaptation (Sanford \& Swezey 2008) and consequently, our conclusions may not hold for dogwhelks at other locations. Compared with many other intertidal ecosystems, Friday Harbor is subjected to widely divergent aerial and aquatic temperature regimes (Helmuth et al. 2002). Thus, even the sister species, $N$. emarginata, which is geographically distributed from Half Moon Bay, California, to Baja California, Mexico (Marko 1998), faces a more restricted range of summer temperatures and may respond very differently to thermal changes than does $N$. ostrina.

\section{CONCLUSION}

Our results clearly demonstrate that changes in aerial and aquatic body temperatures of ectothermic intertidal organisms need not produce similar patterns of organismal response. Moreover, because we observed clear differences in predation activity between aerial and aquatic temperature treatments, these divergent responses will have important repercussions for the entire community. Climate change is likely to cause increases in both aerial and aquatic temperatures of intertidal species (Gilman et al. 2006), and 
accurate predictions of the effect of climate change on these communities will require more studies that use realistic thermal regimes and tidal cycles. Our approach represents an important first step, but a complete picture of responses of intertidal organisms to changing climate requires a much broader assessment that includes simultaneously manipulating both air and water temperatures, assessing response across multiple populations and seasons and determining the effects of organismal body temperature on other ecological interactions such as competition. By realistically defining temperature treatments in conjunction with the appropriate tidal stage and examining both foraging and physiological responses, we can potentially predict the impacts of climate change on intertidal marine ecosystems.

Acknowledgements. We thank B. Helmuth for guidance and support throughout the study. We are also grateful to J. Pinckney, S. Woodin, S. Pincebourde and J. Hilbish for assistance with the experimental design and statistical aspects of this project, and to the faculty and staff at Friday Harbor Laboratories for logistical support and access to both laboratory space and collection sites. Funding for research conducted at Friday Harbor Laboratories was provided by a Stephen and Ruth Wainwright Endowed Fellowship to L.Y. and an FHL postdoctoral fellowship to S.E.G. Additional support was provided by NASA Grant NNG04GE43G to B. Helmuth, D. Wethey, J. Hilbish and V. Lakshmi, and NOAA Grant NA04 NOS4780264 to D. Wethey, B. Helmuth, J. Hilbish, S. Woodin and V. Lakshmi.

\section{LITERATURE CITED}

Angilletta MJ (2009) Thermal adaptation: a theoretical and empirical synthesis. Oxford University Press, Oxford

Bayne BL, Scullard C (1978) Rates of feeding by Thais (Nucella) lapillus (L). J Exp Mar Biol Ecol 32:113-129

Bertness MD, Schneider DE (1976) Temperature relations of Puget Sound thaids in reference to their intertidal distribution. Veliger 19:47-58

Broitman BR, Mieszkowska N, Helmuth B, Blanchette CA (2008) Climate and recruitment of rocky shore intertidal invertebrates in the Eastern North Atlantic. Ecology 89: S81-S90

Brown JH, Gillooly JF, Allen AP, Savage VM, West GB (2004) Toward a metabolic theory of ecology. Ecology 85: 1771-1789

Burnaford JL (2004) Habitat modification and refuge from sublethal stress drive a marine plant-herbivore association. Ecology 85:2837-2849

Burrows MT, Hughes RN (1989) Natural foraging of the dogwhelk, Nucella lapillus (Linnaeus): the weather and whether to feed. J Molluscan Stud 55:285-295

Burrows MT, Hughes RN (1991) Optimal foraging decisions by dogwhelks, Nucella lapillus (L): influences of mortality risk and rate-constrained digestion. Funct Ecol 5:461-475

> Connell JH (1961) Effects of competition, predation by Thais lapillus, and other factors on natural populations of the barnacle Balanus balanoides. Ecol Monogr 31:61-104

Connell JH (1970) A predator-prey system in the marine intertidal region. I. Balanus glandula and several predatory species of Thais. Ecol Monogr 40:49-78

Dahlhoff EP, Buckley BA, Menge BA (2001) Physiology of the rocky intertidal predator Nucella ostrina along an environmental stress gradient. Ecology 82:2816-2829

Dayton PK (1971) Competition, disturbance, and community organization: provision and subsequent utilization of space in a rocky intertidal community. Ecol Monogr 41: 351-389

Dunson WA, Travis J (1991) The role of abiotic factors in community organization. Am Nat 138:1067-1091

Emlen JM (1966) Time, energy and risk in two species of carnivorous gastropods. PhD dissertation, University of Washington, Seattle, WA

Fairweather PG (1988) Movements of intertidal whelks (Morula marginalba and Thais orbita) in relation to availability of prey and shelter. Mar Biol 100:63-68

Fields PA, Rudomin EL, Somero GN (2006) Temperature sensitivities of cytosolic malate dehydrogenases from native and invasive species of marine mussels (genus Mytilus): sequence-function linkages and correlations with biogeographic distribution. J Exp Biol 209:656-667

Gilman SE, Wethey DS, Helmuth B (2006) Variation in the sensitivity of organismal body temperature to climate change over local and geographic scales. Proc Natl Acad Sci USA 103:9560-9565

Glynn PW (1965) Community composition, structure, and interrelationships in the marine intertidal Endocladia muricata-Balanus glandula association in Monterey Bay, California. Beaufortia 12:1-198

Harley CDG, Lopez JP (2003) The natural history, thermal physiology, and ecological impacts of intertidal mesopredators, Oedoparena spp. (Diptera: Dryomyzidae). Invertebr Biol 122:61-73

Helmuth BST (1998) Intertidal mussel microclimates: predicting the body temperature of a sessile invertebrate. Ecol Monogr 68:51-74

> Helmuth B, Harley CDG, Halpin PM, O'Donnell M, Hofmann GE, Blanchette CA (2002) Climate change and latitudinal patterns of intertidal thermal stress. Science 298: 1015-1017

Helmuth B, Kingsolver JG, Carrington E (2005) Biophysics, physiological ecology, and climate change: Does mechanism matter? Annu Rev Physiol 67:177-201

> Helmuth B, Broitman BR, Blanchette CA, Gilman S and others (2006) Mosaic patterns of thermal stress in the rocky intertidal zone: implications for climate change. Ecol Monogr 76:461-479

Hochachka PN, Somero GN (2002) Biochemical adaptation: mechanism and process in physiological evolution. Oxford University Press, New York

Hughes RN, Drewett D (1985) A comparison of the foraging behavior of dogwhelks, Nucella lapillus (L), feeding on barnacles or mussels on the shore. J Molluscan Stud 51: 73-77

Hughes RN, Burrows MT, Rogers SEB (1992) Ontogenic changes in foraging behavior of the dogwhelk Nucella lapillus (L). J Exp Mar Biol Ecol 155:199-212

Jansen JM, Pronker AE, Bonga SW, Hummel H (2007) Macoma balthica in Spain, a few decades back in climate history. J Exp Mar Biol Ecol 344:161-169

Jones KMM, Boulding EG (1999) State-dependent habitat selection by an intertidal snail: the costs of selecting a physically stressful microhabitat. J Exp Mar Biol Ecol 242: 149-177

> Kenny R (1977) Growth studies of tropical intertidal limpet Acmaea antillarum. Mar Biol 39:161-170 
Leonard GH (2000) Latitudinal variation in species interactions: a test in the New England rocky intertidal zone. Ecology 81:1015-1030

Marko PB (1998) Historical allopathy and the biogeography of speciation in the prosobranch snail genus Nucella. Evolution 52:757-774

Menge BA (1976) Organization of New England rocky intertidal community: role of predation, competition, and environmental heterogeneity. Ecol Monogr 46:355-393

Menge BA, Olson AM (1990) Role of scale and environmental factors in regulation of community structure. Trends Ecol Evol 5:52-57

Menge BA, Sutherland JP (1976) Species diversity gradients: synthesis of the roles of predation, competition, and temporal heterogeneity. Am Nat 110:351-369

Menge BA, Sutherland JP (1987) Community regulation: variation in disturbance, competition, and predation in relation to environmental stress and recruitment. Am Nat 130: $730-757$

Menge BA, Olson AM, Dahlhoff EP (2002) Environmental stress, bottom-up effects, and community dynamics: integrating molecular-physiological and ecological approaches. Integr Comp Biol 42:892-908

Mills CE (1984) Density is altered in hydromedusae and ctenophores in response to changes in salinity. Biol Bull (Woods Hole) 166:206-215

Nelson TA (1997) Epiphyte-grazer interactions on Zostera marina (Anthophyta: Monocotyledones): effects of density on community function. J Phycol 33:743-752

Newell RC, Pye VI, Ahsanullah M (1971) Factors affecting the feeding rate of the winkle Littorina littorea. Mar Biol 9: $138-144$

Paine RT (1966) Food web complexity and species diversity. Am Nat 100:65-75

Paine RT (1971) Short-term experimental investigation of resource partitioning in a New Zealand rocky intertidal habitat. Ecology 52:1096-1106

Palmer AR (1980) A comparative and experimental study of feeding and growth in thaidid gastropods. PhD dissertation, University of Washington, Seattle, WA

Palmer AR (1982) Growth in marine gastropods: a nondestructive technique for independently measuring shell and body weight. Malacologia 23:63-73

Palmer AR (1983) Growth rate as a measure of food value in thaidid gastropods: assumptions and implications for prey morphology and distribution. J Exp Mar Biol Ecol 73: 95-124

Parmesan C, Yohe G (2003) A globally coherent fingerprint of climate change impacts across natural systems. Nature 421:37-42

Petes LE, Mouchka ME, Milston-Clements RH, Momoda TS, Menge BA (2008) Effects of environmental stress on intertidal mussels and their sea star predators. Oecologia 156:671-680

Pincebourde S, Sanford E, Helmuth B (2008) Body temperature during low tide alters the feeding performance of a top intertidal predator. Limnol Oceanogr 53:1562-1573

Poloczanska ES, Hawkins SJ, Southward AJ, Burrows MT (2008) Modeling the response of populations of competing species to climate change. Ecology 89:3138-3149

Prosser CL, Brown FA (1961) Comparative animal physiology. WB Saunders, Philadelphia, PA

Editorial responsibility: Gretchen Hofmann,

Santa Barbara, California, USA
Randall D, Burggren W, French K, Eckert R (2002) Animal physiology: mechanisms and adaptations. WH Freeman, New York

Sanford E (1999) Regulation of keystone predation by small changes in ocean temperature. Science 283:2095-2097

> Sanford E (2002a) Water temperature, predation, and the neglected role of physiological rate effects in rocky intertidal communities. Integr Comp Biol 42:881-891

Sanford E (2002b) The feeding, growth, and energetics of two rocky intertidal predators (Pisaster ochraceus and Nucella canaliculata) under water temperatures simulating episodic upwelling. J Exp Mar Biol Ecol 273:199-218

Sanford E, Swezey DS (2008) Response of predatory snails to a novel prey following the geographic range expansion of an intertidal barnacle. J Exp Mar Biol Ecol 354: 220-230

Schiel DR, Steinbeck JR, Foster MS (2004) Ten years of induced ocean warming causes comprehensive changes in marine benthic communities. Ecology 85:1833-1839

Shick JM, Widdows J, Gnaiger E (1988) Calorimetric studies of behavior, metabolism and energetics of sessile intertidal animals. Am Zool 28:161-181

> Somero GN (2002) Thermal physiology and vertical zonation of intertidal animals: optima, limits, and costs of living. Integr Comp Biol 42:780-789

Sorte CJB, Hofmann GE (2005) Thermotolerance and heatshock protein expression in Northeastern Pacific Nucella species with different biogeographical ranges. Mar Biol 146:985-993

Southward AJ, Langmead O, Hardman-Mountford NJ, Aiken $\mathrm{J}$ and others (2004) Long-term oceanographic and ecological research in the Western English Channel. Adv Mar Biol 47:1-105

Spight TM (1982) Risk, reward, and the duration of feeding excursions by a marine snail. Veliger 24:302-308

Stickle WB, Kapper MA, Blakeney E, Bayne BL (1985) Effects of salinity on the nitrogen metabolism of the muricid gastropod, Thais (Nucella) lapillus (L) (Mollusca, Prosobranchia). J Exp Mar Biol Ecol 91:1-16

Stillman JH (2003) Acclimation capacity underlies susceptibility to climate change. Science 301:65

Stillman JH, Somero GN (2000) A comparative analysis of the upper thermal tolerance limits of eastern pacific porcelain crabs, genus Petrolisthes: influences of latitude, vertical zonation, acclimation, and phylogeny. Physiol Biochem Zool 73:200-208

- Walther GR, Post E, Convey P, Menzel A and others (2002) Ecological responses to recent climate change. Nature 416:389-395

Wethey DS, Woodin SA (2008) Ecological hindcasting of biogeographic responses to climate change in the European intertidal zone. Hydrobiologia 606:139-151

Yamamoto T (2004) Prey composition and prey selectivity of an intertidal generalist predator, Muricodrupa fusca (Küster) (Muricidae). PSZN I: Mar Ecol 25:35-49

Yamane LA (2008) Contrasting responses of an intertidal predator to aerial and aquatic body temperatures. MS thesis, University of South Carolina, Columbia, SC

Yee EH, Murray SN (2004) Effects of temperature on activity, food consumption rates, and gut passage times of seaweed-eating Tegula species (Trochidae) from California. Mar Biol 145:895-903

Submitted: January 15, 2009; Accepted: August 19, 2009

Proofs received from author(s): October 15, 2009 